\title{
Comparison of methodologies to estimate the clay content - A case study in the Roncador Field, Campos Basin
}

\author{
Mario Florencio Barreto Paiva ${ }^{1,2}$, Wagner Moreira Lupinacci ${ }^{1}$, Antonio Fernando Menezes Freire ${ }^{1}$, Joanna Hansford ${ }^{2}$ \\ ${ }^{1}$ Universidade Federal Fluminense - UFF \\ ${ }^{2}$ Ikon Science
}

Copyright 2019, SBGf - Sociedade Brasileira de Geofísica

This paper was prepared for presentation during the $16^{\text {th }}$ International Congress of the Brazilian Geophysical Society held in Rio de Janeiro, Brazil, 19-22 August 2019.

Contents of this paper were reviewed by the Technical Committee of the $16^{\text {th }}$ International Congress of the Brazilian Geophysical Society and do not necessarily represent any position of the SBGf, its officers or members. Electronic reproduction or storage of any part of this paper for commercial purposes without the written consent of the Brazilian Geophysical Society is prohibited.

\begin{abstract}
Determination of clay content is one of the most important phases in reservoir characterization. During well evaluation, a variety of different logs and methods can be used to estimate the clay content. Although defining the most appropriate method for the study area, can be a challenge. A comparison between the estimated clay volume from the Larionov method for old rock and clay volumes derived using relationships between the neutron and density logs is presented in the Roncador Field, Campos Basin. Analysis of clay volumes in the wells were performed combined with lithological logs, and the results showed that the method using relationships between the neutron and density logs is more consistent with the interpreted lithologies.
\end{abstract}

\section{Introduction}

It is possible to estimate the clay content using different methods depending on the geology and available data of the study area. As such, errors are not uncommon log evaluations for reservoir characterization.

The gamma ray (GR) log was introduced in late 1930s as the first non-electric logging method (Ellis et al., 2007) and it has been useful in distinguishing between clean and shaley formations. It is also widely used for calculation of the clay volume from empirical models (Rider 2002).

There are some established methodologies which essentially consist of normalizing the GR log, defining the minimum measured values associated with sands and the maximum measured values for shales, and then applying an empirical relationship to calculate the clay volume, such as the methods: linear, Larionov (1969), Stieber (1970), Clavier et al. (1971) and Brock (1984). These are simple methodologies because they depend only on the GR log. The question remains: how valid are methodologies based on the GR log when the reservoir rocks are rich in feldspar with high potassium content?
A methodology less influenced by the natural radioactivity of rocks to calculate the clay volume uses the density and neutron logs. This method may be a more accurate way to calculate the clay volume and can provide a much more consistent result depending on the geological characteristics.

\section{Case Study}

The study area is the Roncador Field, which is located at the northern portion of the Campos basin, approximately $125 \mathrm{~km}$ offshore the state of Rio de Janeiro, with water depth varying from $1500 \mathrm{~m}$ to $1900 \mathrm{~m}$ and within a development area the $398 \mathrm{~km}^{2}$ (Pádua et al., 1998).

The main reservoir rocks in the Roncador Field are turbidite sandstones of deep-marine environment dating from Turonian to Maastrichtian and with average porosity of $25 \%$ and oil with gravities between $17^{\circ}$ and $31^{\circ} \mathrm{API}$ (RANGEL et al., 1998). Petrographic analysis indicates, in average, sandstones with lithic arkose composition with very low quartz to feldspar ratio $(Q / F=0,65)$, and medium grain size (Fetter et al., 2009)

Stratigraphically, these reservoirs (Carapebus Fm.) are intercalated with shales (Tamoios Mb., Ubatuba Fm.). They are identified as RO 200, RO 300 and RO 400 zones (Winter et al., 2007). The wells 9RO33RJS, 9R006ARJS, 9R082RJS and 9R0047RJS were selected for this study because they are representatives of the main geological formations and lithologies present in the Roncador Field. All wells are located in the higher block of Roncador and are oil saturated.

\section{Method}

Clay volumes in all of these wells were estimated using two different methodologies. Clay content was estimated from GR logs using Larionov's equation and also using the neutron (NPHI) and density (RHOB) logs.

The quantitative interpretation of GR logs involves the definition of the sand and shale base lines to determine, respectively, the minimum $\left(\mathrm{GR}_{\min }\right)$ and maximum $\left(\mathrm{GR}_{\max }\right)$ values by the gamma ray $(G R)$ log. Since the GR log is a statistical measure, the $\mathrm{GR}_{\text {min }}$ and $\mathrm{GR}_{\max }$ values must be the mean of minimum and maximum values, respectively. 
These values are used in the calculation of gamma ray index (GRI):

$$
\mathrm{GRI}=\frac{\mathrm{GR}-\mathrm{GR}_{\min }}{\mathrm{GR}_{\max }-\mathrm{GR}_{\min }},
$$

where GR is the value measured by the gamma ray log.

We used the Larionov method (1969) for old rocks in the first estimate of clay volume:

$$
\text { Vclay }=0,33 *\left(2^{2 * \mathrm{GRI}}-1\right) \text {. }
$$

Although the estimation of Vclay from GR log is a very popular technique (Nery, 2013), it is necessary evaluate the applicability and validation of this method, because its range can be limited if the rock matrix has a minimum trace of radioactive material, such as feldspar, or if GR log cannot clearly distinguish sands and shales in the analyzed area (Stevanato, 2011).

The clay volume was also calculated from the neutron (NPHI) and density (RHOB) logs using the equation (Bhuyan and Passey, 1994):

$$
\left.\operatorname{Vclay}_{(\mathrm{NPHI}}, \mathrm{RHOB}\right)=\frac{\mathrm{X}_{1}-\mathrm{X}_{0}}{\mathrm{X}_{2}-\mathrm{X}_{0}},
$$

where $\mathrm{X}_{0}$ is the mean of the maximum values measured in the neutron log, and:

$$
\begin{gathered}
\mathrm{X}_{1}=\mathrm{NPHI}+\mathrm{M}_{1}\left(\mathrm{RHOB}_{\text {matrix }}-\mathrm{RHOB}\right), \\
\mathrm{X}_{2}=\mathrm{NPHI}_{\text {shale }}+\mathrm{M}_{1}\left(\mathrm{RHOB}_{\text {matrix }}-\mathrm{RHOB}_{\text {shale }}\right), \\
\mathrm{M}_{1}=\frac{\mathrm{NPHI}_{\text {fluid }}-\mathrm{NPHI}_{\text {matrix }}}{\mathrm{RHOB}_{\text {fluid }}-\mathrm{RHOB}_{\text {matrix }}}
\end{gathered}
$$

where $\mathrm{NPHI}_{\text {matrix }}$, $\mathrm{NPHI}_{\text {shale }}$ and $\mathrm{NPHI}_{\text {fluid }}$ are, respectively, the values measured in a zone $100 \%$ with matrix (sand or calcite), shale or fluid of the neutron log.

$\mathrm{RHOB}_{\text {matrix }}, \mathrm{RHOB}_{\text {shale }}$ and $\mathrm{RHOB}_{\text {fluid }}$ are, respectively, in a zone $100 \%$ with matrix (sand or calcite), shale or fluid of the density log.

An advantage of this method is that if there is no gas in the formation, the response tends to be linear for the fluid content of the rocks. This is because the neutron log is very sensitive to the high hydrogen content of the clays, and the density log is not. In general, clay minerals contain a high hydrogen index and the quartz, calcite and dolomite minerals do not.

Finally, the results of the clay volume estimates were analyzed with the lithological logs.

\section{Results}

In Figure 1, the GR, density - neutron and lithological logs of the wells 9RO33RJS, 9RO06ARJS, 9RO82RJS and
9RO047RJS are showed. Note that it is not possible to identify the type of lithology only from the GR logs and the average values of $\mathrm{GR}$ to these wells are $110^{\circ} \mathrm{API}, 98^{\circ} \mathrm{API}$, $93^{\circ} \mathrm{API}$ and $77^{\circ} \mathrm{API}$ respectively, which are high values for

\begin{tabular}{|c|c|}
\hline \multicolumn{2}{|l|}{ Sandstones } \\
\hline Limestones & 10 \\
\hline Shales & \\
\hline Marls & \\
\hline Siltstone & $\because 9090$ \\
\hline
\end{tabular}
sandstones.

The lithology logs were defined using the mud logging interpretation and follow the lithologies has found in Roncador Field (table 1)

Table 1 - Legend of the lithologies.

Figure 2 shows the estimate clay volumes from both methodologies. Vclay (Larionov) and Vclay (Neutron-Density) are indicated by a red polygon and compared side by side. An initial analysis shows that each method provides a different result.

Clay volumes are indicated as a normalized volume fraction which provides a more accurate matrix definition of the rocks, reducing the risk of mixing the wrong volume fraction. In these volume fractions, green curves are indicating shales (or non-reservoir zones) and yellow are sands (reservoir zones). The mineral mixing type was defined through weighting Voigt-Reuss-Hill relation assuming the same weight for upper bulk modulus $(K)$ and upper shear modulus (Mu) (Avseth et al., 2005).

\section{Discussion}

In sandstones and limestones, the Larionov method estimates values greater than the method using the NPHI and RHOB logs. This could lead to an interpretation of a clay-rich sandstone reservoir, thereby masking the qualities of the reservoir.

In the shale and marl facies, the NPHI-RHOB method was consistent with the interpreted lithological logs. Whereas, the Larionov method underestimated the clay content values, implying it was an inappropriate method to estimate this property.

In sandstone reservoirs of the Roncador Field, the GR log is not indicated to estimate the clay volume due to the presence of feldspars, which is a radioactive mineral, due to the presence of the isotope $K^{40}$, thus influencing the measurements. This mineral can cause anomalous measurements on the GR log to clean sands and it cannot clearly differentiate sands and shales in most intervals, i.e. these measurements have high values for the reservoir and non-reservoir rocks. As the Larionov method dependent on the GR log, the Vclay(Larionov) carried the shape of this log.

The estimated clay volumes from NPHI-RHOB logs obtained results more coherent with the lithology logs, delimiting all reservoirs and non-reservoirs intervals accurately. 
Figure 3 shows Vsh (Larionov) and $V_{s h}$ (Neutron-Density) curves and the lithology logs. Reservoirs are highlighted in red and the non-reservoir zones are in black.

In wells 9R0033RJS and 9R006ARJS where the main reservoir RO 330 was identified, the lithology log indicates essentially a sand-shale system with interbedded marls more clearly in well 9RO06ARJS and several thin limestones layers interbedded at the base of RO 330 in well 9R0033RJS. Reservoir RO 400 was interpreted as a thin layer in these both wells. Analyzing these results, the Larionov method doesn't offer accurate/or consistent shale content compared with the lithology log. But the fit is better if $\mathrm{Vsh}_{\text {(Neutron-Density) }}$ is compared to lithology log.

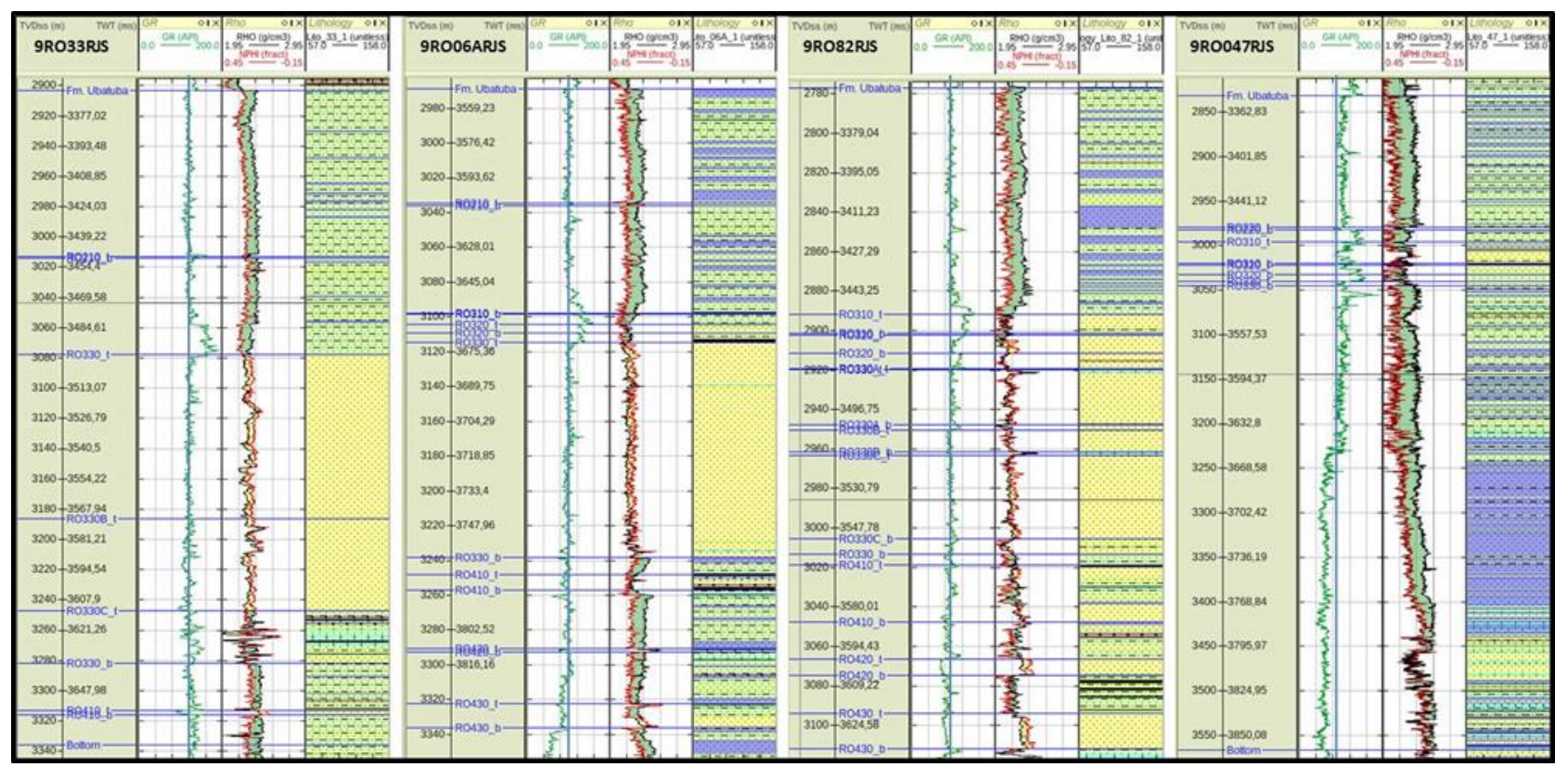

Figure 1 - GR (with a thresholder line indicating the average value), density (RHOB) - neutron (NPHI) and lithology logs of the wells 9RO33RJS, 9RO06ARJS, 9RO82RJS and 9RO047RJS.

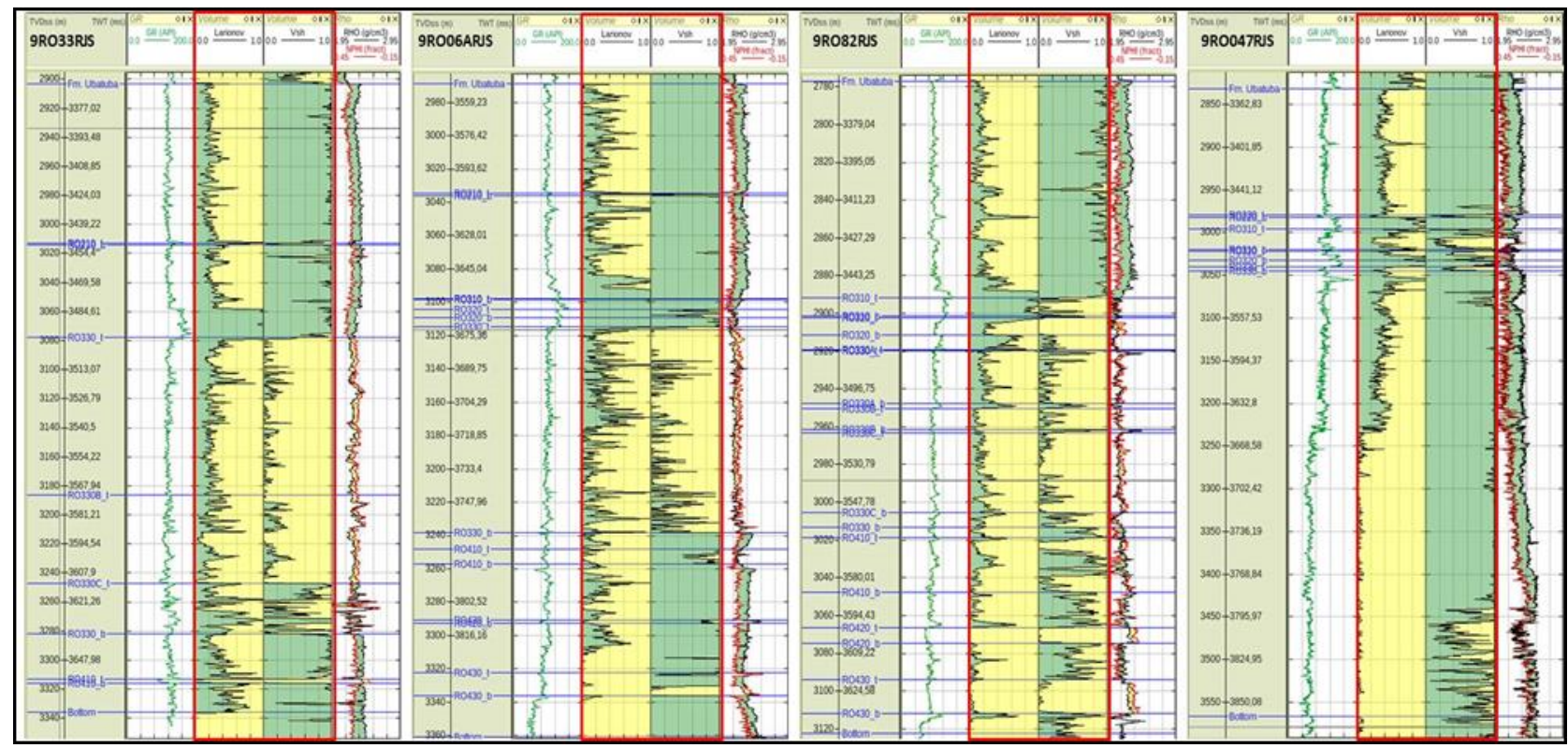

Figure 2 - Comparison of clay volume estimates in all wells (9RO33RJS, 9RO06ARJS, 9RO82RJS and 9RO047RJS). Wells are displaying GR, Vclay(Larionov), Vclay (Neutron,Density) $_{\text {and }}$ RHOB versus NPHI logs respectively. 
Well RO82RJS shows a large reservoir interval interbedded with some non-reservoir shales, marls and siltstones. All RO 300 and 400 zones were identified here. Once more, is possible see that Vclay (HPHI-RHOB) is a more sensible fit for these lithologies and provided an accurate model for clay content delimitating reservoirs and nonreservoirs compared to Vclay (Larionov).

Well 9RO047RJS, there are some thin marls interbedding at overburden, however below the reservoir RO 320 there is a large marl interval that the Vclay indicated as some possible reservoir zone, which is in disagreement with the lithology log.

The Namorado Sandstone, another zone of Roncador Field, was also identified at the final section of the well, displaying an excellent fit between Vclay (HPHI-RHOB) and the lithology logs.

\section{Conclusions}

The limitation of the Larionov method was evident in estimation of the clay content in reservoirs of Roncador Field. The lithology logs assist in the delineation of the reservoirs and non-reservoirs zones, described as limestones, marls and siltstones. In this study, mineral volume curves were not available for the non-reservoir lithologies, as such, it was not possible build a complete volume fraction set including all lithologies. However, as the production zones in these wells are turbidites, it allowed for the use of the clay volume from the neutron and density logs to create a volume set considering a sand-shale system. Since these curves delivered precise information about reservoirs and non-reservoirs zones, even without other lithology curves. This factor demonstrates that the Larionov method is not suitable for the Roncador Field which contains radioactive sands with high feldspar content. Further to this, any other empirical relationship to estimate the clay volume based solely on GR logs are unlikely to provide accurate results in the study area. The use of established methods does not necessarily guarantee accurate results. Integration of all available data together with the correct application of these methods and analysis of published materials is crucial to providing a better geological model.

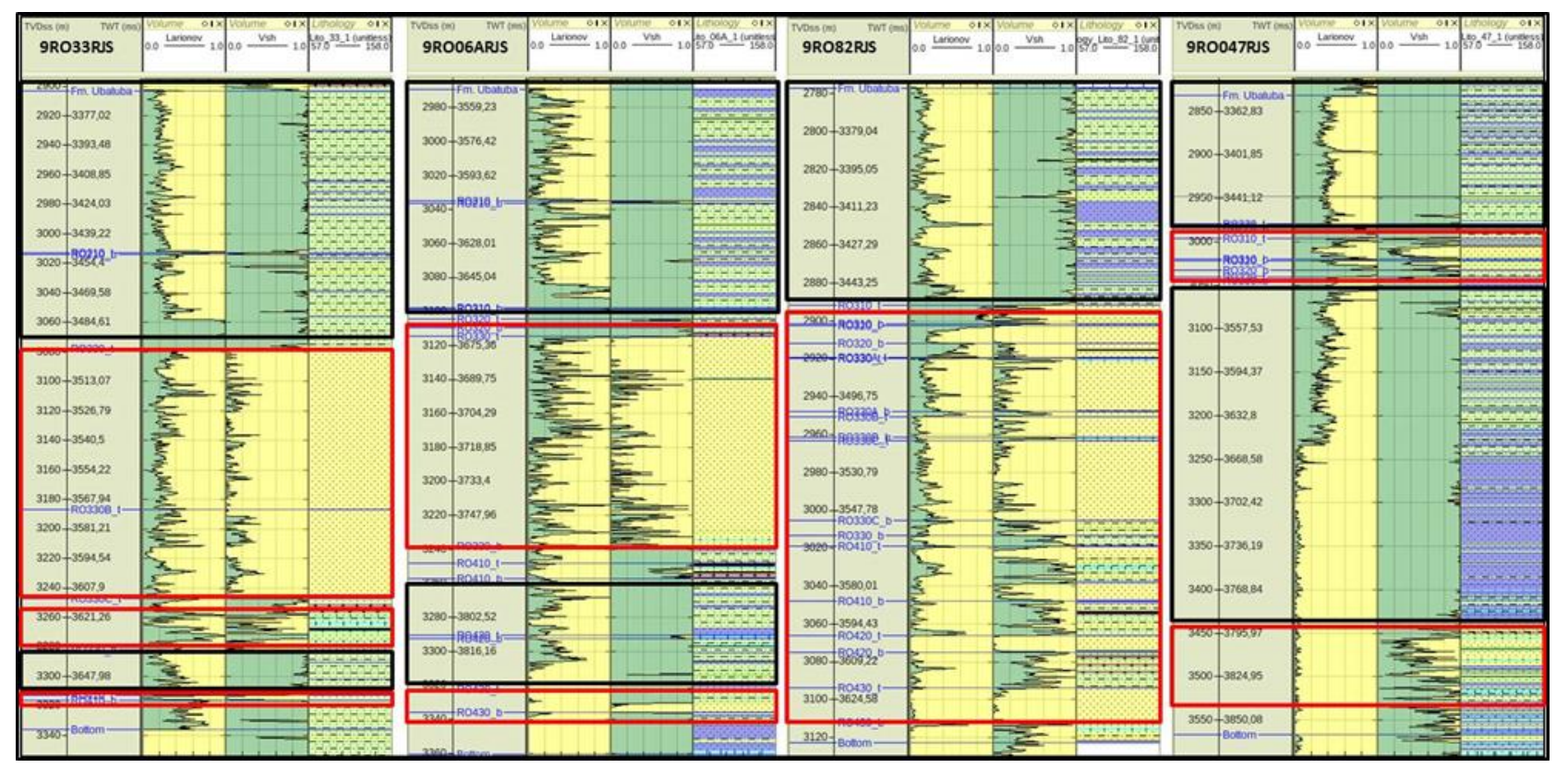

Figure 3 - Comparison of clay volume estimates in all wells (9RO33RJS, 9RO06ARJS, 9R082RJS and 9RO047RJS). Wells are displaying, Vsh(Larionov), $V_{\text {sh }}$ (Neutron,Density) and Lithology logs, respectively.

\section{Acknowledgments}

We thank Ikon Science Limited for providing access to the RokDoc software and the Agência Nacional do Petróleo, Gás Natural e Biocombustíveis (ANP) for providing data to perform this work.

\section{References}

AVSETH, P., MUKERJI, T., AND MAVKO, G., 2005, Quantitative Seismic Interpretation: Cambridge University Press.
BHUYAN, K. AND PASSEY, Q., 1994. Clay estimation from GR and neutron-density porosity logs. In: Society of Petrophysicists and Well-Log Analysts (ed.), Proceedings of the SPWLA 35th Annual Logging Symposium, 19-22th Jun 1994, Tulsa, Oklahoma, USA, pp. $1-15$.

BROCK, J., 1984. Analysing your logs: Advanced Open Hole Log Interpretation, Petromedia, 173 pp., Vol. 11.

CLAVIER, C.; HOYLE, W. R.; MEUNIER, D., 1971. Quantitative interpretation of TDT logs. Parts 1 e 2: Journal of Petroleum Technology, vol. 23, p.743-763. 
ELLIS, D. V.; Singer, J. M., 2007. Well Logging for Earth Scientists. Springer, 2.ed., Dordrecht, The Netherlands, 692 p.

FETTER, M. ; DE ROS, L. F. ;.BRUHN, C. H. L. ; 2009 Petrographic and seismic evidence for the depositional setting of giant turbidite reservoirs and the paleogeographic evolution of Campos Basin, offshore Brazil. Marine and Petroleum Geology 26: 824853

LARIONOV, W. W., 1969. Radiometry of boreholes, NEDRA, Moscow.

NERY, G. G., 2013. Perfilagem Geofísica em Poço Aberto - Fundamentos Básicos com Ênfase em Petróleo. Sociedade Brasileira de Geofísica - SBGf. Rio de Janeiro. Brasil. ISBN 978-85-88690-19-6

STIEBER, S. J. Pulse Neutron capture log evaluation in the Louisiana Gulf Coast. Annual meeting of SPE, Houston, p. 4-7, October, 1970.
WINTER, W.R.; JAHNERT, R.J. \& FRANÇA, A.B. 2007. Bacia de Campos. Boletim de Geociências da Petrobrás, $15(2): 511-529$.

PÁDUA, K.G.O., STANK, C.V., SOARES, C.M., MOREIRA, J.V. "Roncador Field, Strategy of Exploitation". Offshore Technology Conference, OTC8875-MS, Houston, Texas, USA, 4-7 mai. 1998.

RANGEL, H. D. \& MARTINS, C. C., 1998. Principais compartimentos exploratórios, Bacia de Campos. In: (ed.) Searching For Oil and Gas in the Land of Giants. Rio de Janeiro, Schlumberger 32-40

RIDER, M., 2002. The Geological Interpretation of Well Logs. Rider-French Consulting Ltd, 2.ed., Sutherland, Scotland, 280p.

STEVANATO, A.C.R.S., 2011. Análise Petrofisica de Reservatórios. Campinas, Graduação em Geologia. Universidade Estadual de Campinas. 